\section{ECONOMICS}

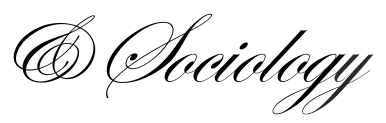

\title{
ATTITUDES OF YOUNG PEOPLE TO JOB SEARCHING THROUGH SOCIAL MEDIA: CASE OF SLOVAKIA
}

\begin{abstract}
Successful Processes and tools for job searching for different positions are changing in present time. Social media are more important in job searching than any time before. This article is dealing with attitude of young people to job searching through social media. We are focused in our research on university students. The main aim of the article is identify present importance of social media in job searching and behavior of students on social media and their attitudes to possibilities of job searching through social media. The research was done by questionnaire survey on the group of students of Faculty of Social and Economic Relations, Alexander Dubček University of Trenčín. The survey was conducted in March - April 2016. We formulate deductions; identify trends and the future of social media in job searching.
\end{abstract}

DOI: $10.14254 / 2071-$

789X.2017/10-1/11

JEL Classification: J20, J24

Keywords: social media, job searching, recruiting, university students, Slovakia.

\section{Introduction}

Unemployment is still one of the biggest problems in Slovakia. It's a problem mostly for elder people (elder then 50 years of age), but we have also problem with unemployment of young people. According to the Slovak statistical office, unemployment rate in Slovakia was $9.5 \%$ in the third quarter of 2016 (ŠÚ SR, 2016) and 8.76\% in December 2016 (UPSVAR, 2017). The unemployment rate of young people (under 25 years) was $19.03 \%$ in December 2016 (UPSVAR, 2017). In this indicator Slovakia belongs to the worst 7 countries of EU together with Spain, Portugal, Italy, Croatia, Cyprus and Greece. Also a lot of young people after graduate search their job in foreign countries like Czech Republic, United Kingdom, Ireland, Austria and Germany.

The way of looking for a job has notably changed within the last ten years. From the origin paper advertisements in newspapers through specialized (online) work portals which are as agents between candidates and employers to social media. Nowadays social media play important role also in looking for a job. HR managers use social media to look for the right 
candidates very often. They are able discover a lot of information about potential candidate. Internet based social media offers information such as candidate's abilities, hard and soft skills, realized projects and also some information from candidate's private life which can be also useful. We can speak about social recruiting. We're living in a hyper connected world that moves at the speed of push notifications, tweets and text messages. Recruiters can no longer see a candidate as just a candidate. Instead they need to see candidates as potential customers, partners, and future employees regardless of their current experience level or fit within their company (Miller-Merrell, 2016). Study which was done by social media monitoring service reppler.com found that more than $90 \%$ of recruiters and hiring managers have visited a potential candidate's profile on a social network as part of the screening process. And a whopping $69 \%$ of recruiters have rejected a candidate based on content found on his or her social networking profiles - an almost equal proportion of recruiters (68\%), though, have hired a candidate based on his or her presence on those networks (Swallov, 2011). On the other hand candidates use internet and specialized portals for looking for a suitable occupation.

In the last years social media contribute to this role. Majority of companies use social network for external communication. Accordance to Leonardi, Huysman and Steinfield we can talk about enterprise social media (Leonardi et al., 2013). In 2013, more than half of all recruitment activity involved the Internet (53\%), with the percentage for 2014 forecasted to continue to grow (615 out of 10 job seekers use social media for job search purposes and 7 out of 10 recruiters use social media for their daily HR activities. $29 \%$ of job seekers have been contacted through social media by a recruiter at least once, and $9 \%$ received a job offer. (Zanella, Pais, 2014). In 2016, recruitment agencies and personal contacts/referrals were used by a greater number of candidates than any of the other channels $(66 \%)$, with Internet job boards coming in third place (56\%). Social media generated applications from $49 \%$ of candidates this year (up from $45 \%$ ). The applications made via social media reverses last year's drop and jumps to a $15.9 \%$ share of applications made. The data reflects a further increase in the percentage of candidates that make any application via social media (up to $49 \%$ from $45 \%$ ). Interestingly, following a fall last year, the share of total applications has increased this year - up to $15.9 \%$ from $12.1 \%$ last year (Top-Consultant, 2016).

Given the high take-up of social media platforms compared to the comparatively low total share of applications generated by the channel (15.9\%), respondents use social media for expanding professional networks remains, it is the most common driver of social media's use. Applying for advertised job positions remains unchanged in 5th place in 2016.

From job searching point of view the most used social network is a platform LindedIn.com which was launched primarily to link professionals from different businesses and at the same time it is optimized for looking for a job.

In Slovakian conditions the next one is Facebook.com. Even it is primarily designed to other purpose human resources managers use it very often to get information about potential candidates. Facebook is the most wide spread social media in Slovakia. Other social media do not play an important role.

LinkedIn is considered without a doubt to be the most effective social networking site in terms of matching Job Seekers with open positions. The effectiveness index of LinkedIn is 0.13 (the index assumes values between -1, lowest effectiveness, and 1, highest effectiveness). Among the others, Facebook rates at -0.29 and therefore, is considered to be a "less ineffective" social networking site. These rates are considerably lower than those gathered among recruiters, where LinkedIn is rated at 0.60 and Facebook is positively assessed (0.05) (Zanella, Pais, 2014).

The vast majority of consultants have an active profile (defined as being accessed at least once a week) on a social media platform and LinkedIn is still the clear leader with $90 \%$ 
of respondents using the platform. The use of Facebook and Twitter, second and third in this ranking respectively, has fallen for the second year running in both cases (Top-Consultant, 2016).

Zheng and Cheok analysed in Singapore young people's use of social networks. While in 2008 only $30 \%$ of the young people from Singapore made use of social networks, by 2011 $99 \%$ of young people between 7 and 24 years of age had become social network users (Zheng, Cheok, 2011).

In our research we focused on attitudes of young people (university students) to social media and their potential to be significant tool for job searching and searching for business opportunities. In this aim group is life on virtual world and on digital platforms as social networks very typical.

The paper deals with social media and its role in looking for a job of young people (students in university). We analyze questionnaire survey carried out at Faculty of social and economic relations and its students.

\section{Social media and their role in job searching}

Social media is a group of Internet-based applications that build on the ideological and technological foundations of Web 2.0, and that allow the creation and exchange of usergenerated content (Kaplan, Haenlein, 2010). Social network is a web service allowing an individual to create public or semi-public profile within limited system interconnected with other users who they share content with, and it allows them to look through and list the connections with other users within this system (Boyd, Ellison, 2007).

There currently exists a rich and diverse ecology of social media sites, which vary in terms of their scope and functionality. Some sites are for the general masses, like Facebook. Other sites, like LinkedIn, are more focused to professional networks. Media sharing sites, such as MySpace, YouTube, and Flickr, concentrate on sharing videos and photos (Kietzmann et al., 2011).

Why are social media so attractive and why young people use social media? According to Colas, Gonzalez and de Pablos the driving force behind this use falls between two extremes: seeking to cover the social need young people have to share experiences, and activity being recognised by others, thus establishing new social relationships. Regarding young people's motivations, these are preferably of an individual nature, aimed at covering an emotional dimension; the social network is a virtual space that is emotionally gratifying and allows young people to express their intimate feelings through the perception others have of them (Colas et al., 2013). Social media seem to offer appealing and valuable opportunities to attract and engage talented young individuals, sustaining the quality, quantity, and fairness of employment relationships (Bissola, Imperatori, 2014).

Most typical characteristic features of the youngest age-groups are the following: they have too much self-confidence, they are creative, they have strong career desires and their communication is perfect while they are not at all moderate, committed or work hard (Bencsik et al., 2016).

Young people under 25 years and university students significantly affect the labour market. They are part of Generation Y or Millenials. People born after 1990 and younger current graduates are looking for job opportunity. Some of Generation Y members (born between 1980 and 1990) are on position of recruiters in companies or working agencies or they work like headhunters. All of this people use social media directly in work. Millenials are changing the recruiting industry. An Aberdeen study found that 73\% of 18-34 year olds found their last job through a social network (Parker, 2014). 
The modern job seeker uses multiple methods to find the perfect job. $24 \%$ of respondents in Job seeker nation study 2016 done by Jobvite.com say that employee referrals helped them find their most fulfilling job. $48 \%$ used social media in the search for their most recent job - of those, 67\% used Facebook, and only 35\% used Twitter. 59\% have used social to assess the company culture of a potential employer. People are searching for jobs anytime, anywhere: $52 \%$ of mobile job seekers have looked for new opportunities while in bed, and $37 \%$ have searched while at the office at their current job (Jobvite, 2016).

\subsection{The aim and methodology of the research}

We decide to focus a survey on the analyses of utilization of social media by university students. We analyse also approach and attitudes of students to job searching through social media. The survey was done by department of Management and human resources development on Faculty socio-economic relations.

Job search is a crucial step for university graduates' school-to-work transition, which involves the identification of employment goal and pursuit of that goal (Boswell et al., 2012) The survey was done in February and March 2016 through questionnaire. 237 respondents participated in the survey - students of Faculty of social and economic relations at Alexander Dubček University of Trenčín. In the survey group there was 53 male (22.4\%) and 184 female (77.6\%), students of all 5 year-classes of university study. Almost all of these students were born between year 1990 and 1995. They are younger part of Generation Y - future graduates, mostly in the next 3 years. In the Faculty of Social-economic Relations study 794 students in full -time study. The survey was conducted in beginning of summer semester, so it is very probable, that a lot of students in 5 class year is on the process of job searching, or they are thinking about future job much than younger students.

The survey consists of 24 mostly closed questions. 2 types of answers were offered in the questionnaire. Respondents were allowed to choose easily from answers (to tick off only 1 possible answer) in most of questions in the questionnaire (13 questions). In two questions respondent had the possibility to tick off more than one answer.

The first part of the questionnaire examined socio-demographic characteristics of respondents; it means data about age, gender, year-class of respondents. Second part is monitoring utilization of social media by students (type, frequency of use, purpose) and their behaviour on the social networks. Third part is focused on possibilities of job searching on social media percept by students. The last section is focused on utilization of facebook.com and LinkedIn.com by students and some questions are dedicated to privacy issues on facebook.com. As far as the article size is limited there are presented only results of selected questions from the questionnaire.

All data have been rounded according to the principles of mathematical rounding to one (tables) or two (graphs) decimal places. For that reason, may not form a precise amount of $100 \%$. The percent of respondent, who answered particular questions is calculated as a share from number of respondents who answered corresponding question.

\section{Results of research}

237 respondents participated in the survey. Most of them $(46.4 \%)$ have between 23 and 24 years of age as mentioned in Table 1 below. 
Table 1. Number of survey participants by age

\begin{tabular}{lcccc}
\hline \multicolumn{1}{c}{ Categories } & Under 20 years & 20 to 22 years & 23 to 24 years & 25 and more years \\
\hline Number & 11 & 88 & 110 & 28 \\
\hline Percentage $(\%)$ & 4.6 & 37.2 & 46.4 & 11.8 \\
\hline
\end{tabular}

\section{Source: Authors.}

Most respondents $(41.8 \%)$ study in 5 year-class at the university. Students in 5 yearclass are according to the topic of the survey the most important. They are young people who will become successful graduates of the university in a half a year. Number of respondents by year-classes is in the Table 2 below.

Table 2.Number of survey participants by year-classes

\begin{tabular}{lccccc}
\hline \multicolumn{1}{c}{ Categories } & $\begin{array}{c}1^{\text {st }} \text { year of } \\
\text { study }\end{array}$ & $\begin{array}{c}2^{\text {nd }} \text { year of } \\
\text { study }\end{array}$ & $\begin{array}{c}3^{\text {rd }} \text { year of } \\
\text { study }\end{array}$ & $\begin{array}{c}4^{\text {th }} \text { year of } \\
\text { study }\end{array}$ & $\begin{array}{c}5^{\text {th }} \text { year of } \\
\text { study }\end{array}$ \\
\hline Number & 32 & 42 & 39 & 25 & 99 \\
\hline Percentage $(\%)$ & 13.5 & 17.7 & 16.5 & 10.5 & 41.8 \\
\hline
\end{tabular}

Source: Authors.

In the next Figure 1 we can see which social media use (as active user) our respondents from survey.

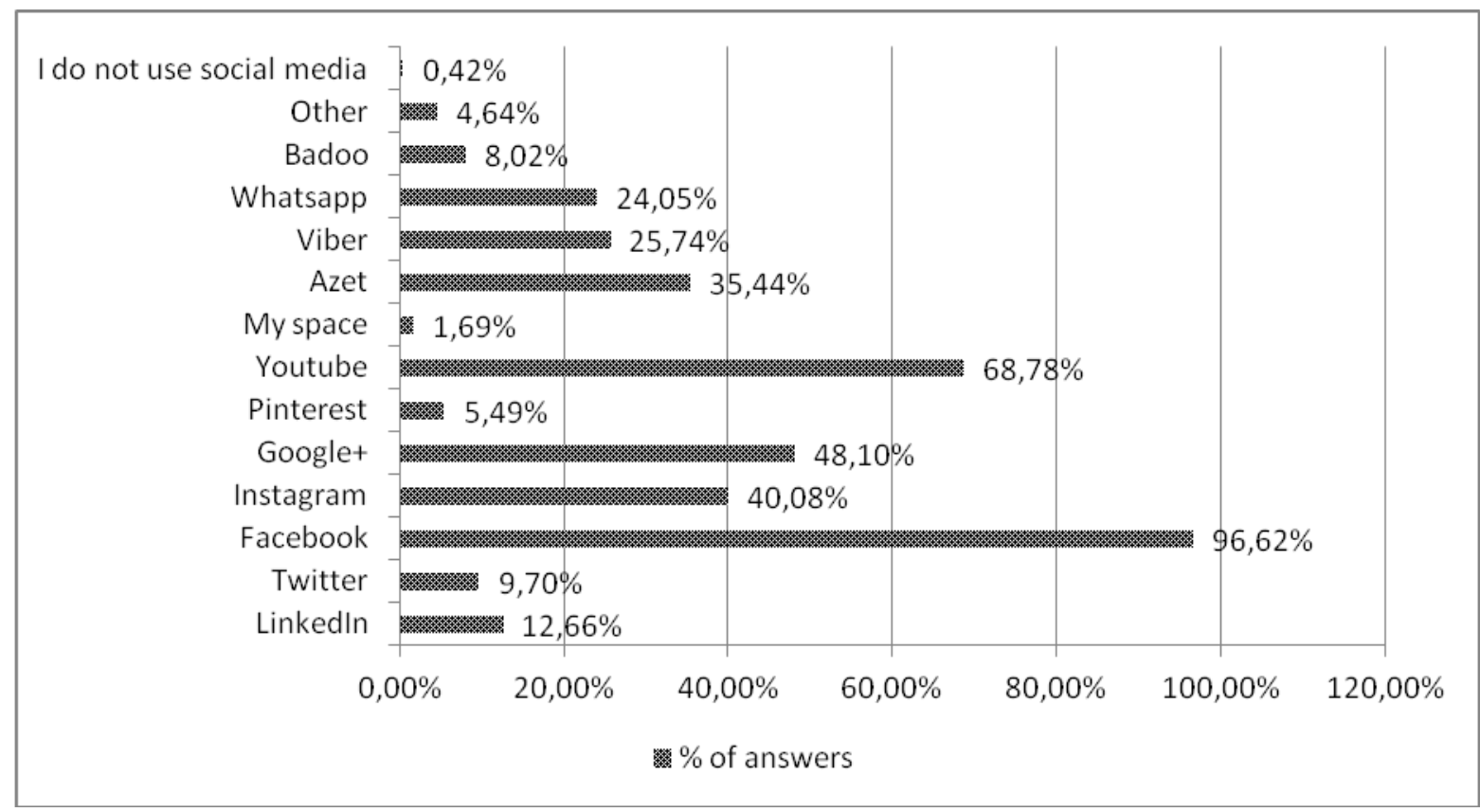

Figure 1. Which social media do you use?

Source: Authors.

Very interesting is a comparison in which social media are students from the survey active. More than $96.6 \%$ of respondents are using facebook.com. It is not a surprise. Facebook is the most widespread social media globally and also in Slovak republic. Video 
sharing network Youtube.com is on the second place $(68.8 \%)$ and Google+ with $48.1 \%$ of users is on the third place. Slovak social network Azet.sk with $35.4 \%$ is on the fourth place. According our aim is interesting position of professional social network LinkedIn. It is on the eight place and it is used by $12.6 \%$ of respondents. Most of University students in our survey prefer fun, relax and non conformity so they prefer social media which main role is non formal communication, entertainment and of course games.

We investigated how students characterize themselves as users of modern ICT devices (smartphones, PC, notebooks, tablets) $(\mathrm{n}=237) .26$ of them $(11.0 \%)$ characterize themselves as intense user, $200(84.4 \%)$ as active users and only 10 of them $(4.2 \%)$ as passive users. Only 1 respondent from the dataset $(0.4 \%)$ do not use any ICT devices. This numbers refer to Table 3 below. It is corresponding to another surveys and researches. Based on the age, 90\% of 14-17 years old population is intense and active user Internet, $81 \%$ of 18-24 years old, $69 \%$ of 25-34 years old, 59\% of 35-44 years old, $47 \%$ of $45-54$ years old, $37 \%$ of 55-59 years old, and 5\% of 60 and more years old in 2015 (Velšic, 2015).

Table 3. How do you characterize yourself as user of ICT devices?

\begin{tabular}{lcccc}
\hline \multicolumn{1}{c}{ Categories } & Intense user & Active user & Passive user & I do not use any ICT devices \\
\hline Number & 26 & 200 & 10 & 1 \\
\hline Percentage $(\%)$ & 11.0 & 84.4 & 4.2 & 0.4 \\
\hline
\end{tabular}

Source: Authors.

We also investigated how students characterize themselves as social media users $(n=236) .19$ of them $(7.2 \%)$ characterize themselves as intense user, $189(80.1 \%)$ as active users and $27(11.4 \%)$ of them as passive users. Only 1 respondent from the dataset $(0.4 \%)$ do not use any social network. This numbers refer to Table 4 below.

Table 4. How do you characterize yourself as a social media user?

\begin{tabular}{lcccc}
\hline \multicolumn{1}{c}{ Categories } & Intense user & Active user & Passive user & I do not use any social media \\
\hline Number & 19 & 189 & 27 & 1 \\
\hline Percentage $(\%)$ & 8.1 & 80.1 & 11.4 & 0.4 \\
\hline
\end{tabular}

Source: Authors.

Students are very active in social media. The next question refers to how many hours in average they spend on social media sites daily $(n=236)$. More than $2 / 3$ of respondents spend more than 2 hours daily on social media sites (on PC, tablets and of course on smartphones). More than $30 \%$ of respondents spend on social media 4 and more hours a day. Accurate numbers we can see in the Figure 2 below. 
RECENT ISSUES IN SOCIOLOGICAL RESEARCH

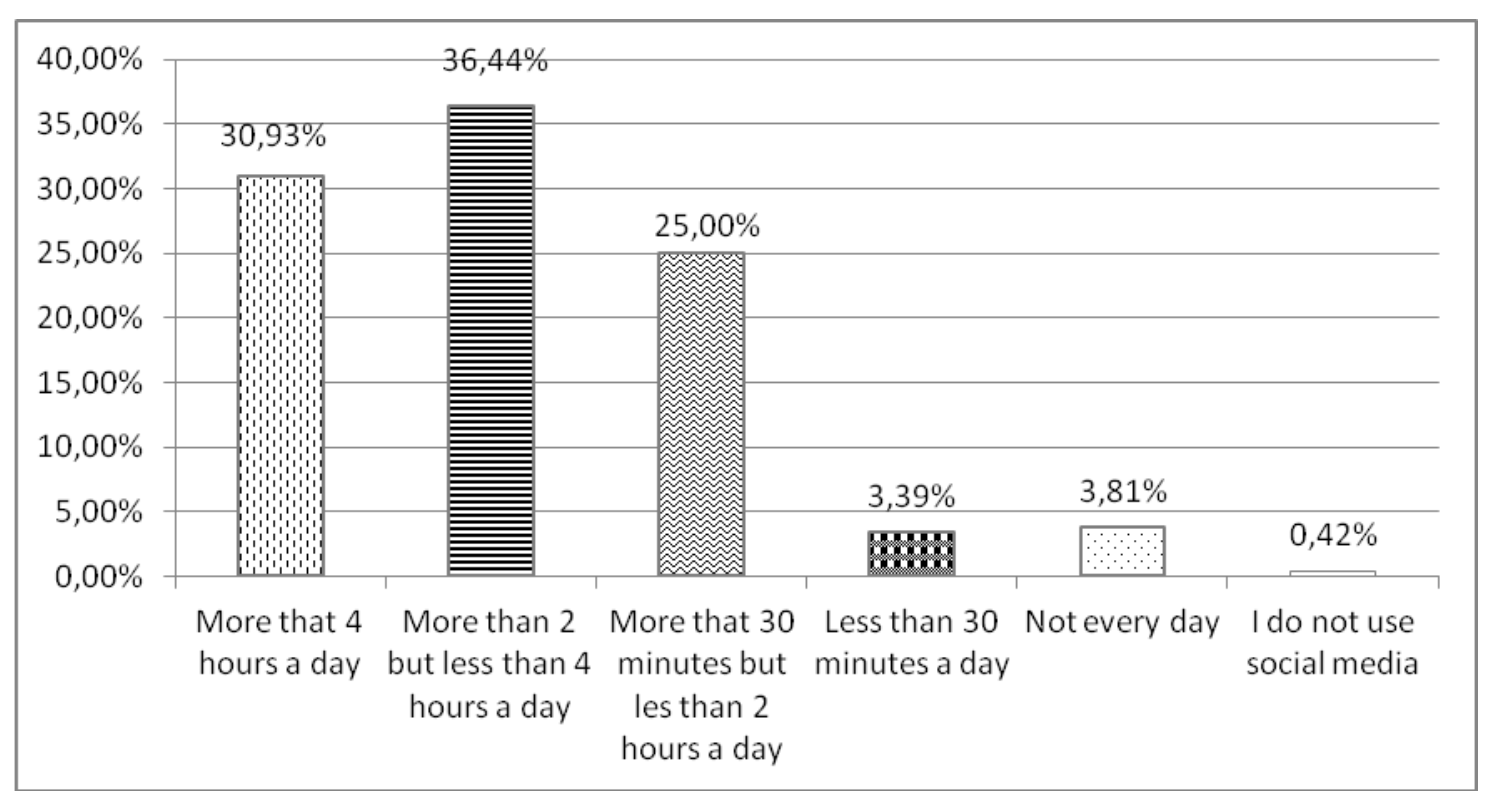

Figure 2. How many hours in average you spend on social media sites daily? Source: Authors.

As we can see the time spend on social media sites is really huge. People from the young generation are very active in social network and use more and more mobile devices. They connect everywhere, especially where is free Wi-Fi connection.

We also investigate if students in the past use possibility of internet for searching a job. We asked on possibility of job portal or advertisement on the web except social networks. The data is representing on the figure below.

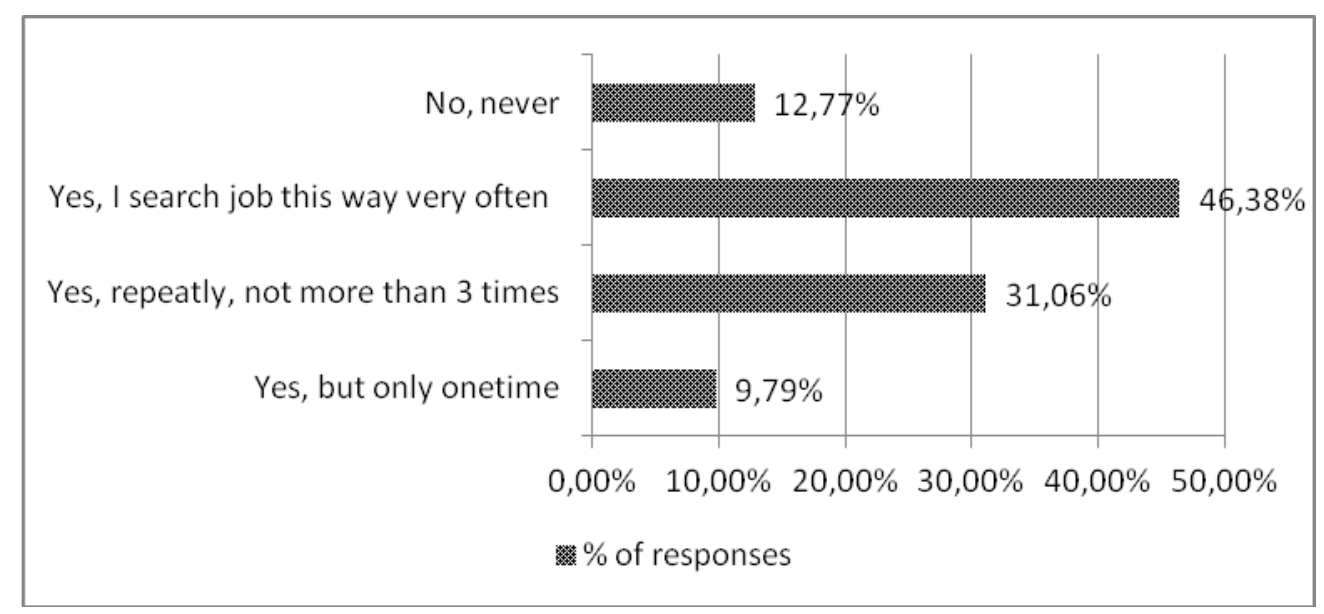

Figure 3. Did you use internet - job portals, advertisement on web for job searching (except social networks)

Source: Authors.

We can claim that university students from Faculty of social-economic relations very often search job through internet. Only 30 (12.8\%) respondents never use internet for job searching. On the other side more than $77 \%$ of respondents use internet for job searching at least once. 
Based on the age, $22.2 \%$ of 16-24 years respondents looking for a job or sending a job application, and $5.1 \%$ of 16-24 years respondents participating in professional networks (creating user profile, posting messages or other contributions to Linkedln, Xing,etc.) in 2013 (Vlačuha et al., 2013).

In the next question we asked if students use social media for looking for a work occasions. Only 218 students responded to this question. 27 of them (12.4\%) use social media for looking for a work occasions significantly, 80 of them $(36.7 \%)$ average 55(25.2\%) rare and $56(25.7 \%)$ of them do not use social media for looking for a work occasions. Detailed data represent the Figure 3 below.

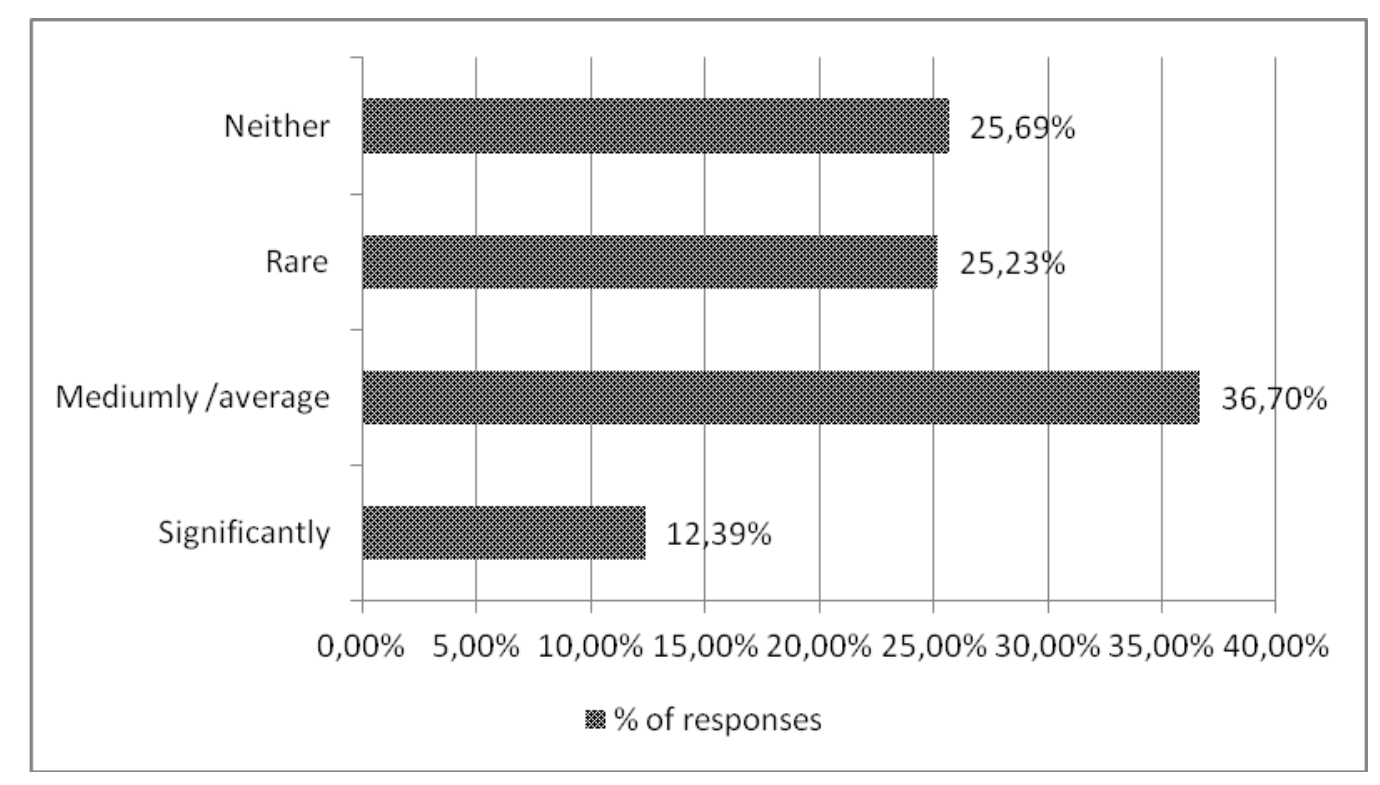

Figure 4. Do you use social media for looking for a work occasions?

Source: Authors.

In the question if they have ever got a job offer through any social media, student answered that almost half of them got offer for a job through social media more than one time (48.3\%). $20.3 \%$ of respondents answered that they got job offer through social media only one time. Almost one third of respondents (31.4) answered that they never got a job offer through social media. This question was answered by 236 respondents. Detailed data represent the Figure 4 below. 
RECENT ISSUES IN SOCIOLOGICAL RESEARCH

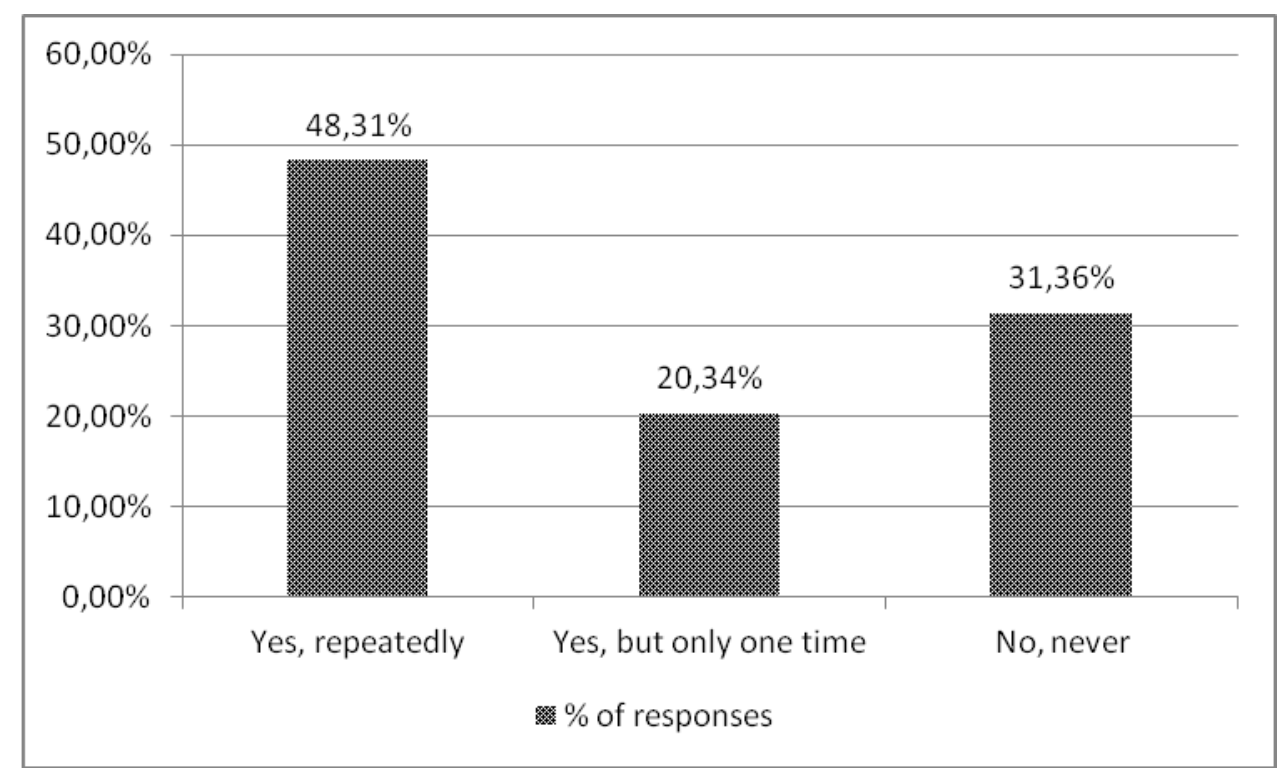

Figure 5. Have you ever got a job offer through any social media?

Source: Authors.

As we can see university students have a lot of work offers through social media. In the survey we don't investigate complexion of this offer. It could be a job offer for long-term contract, brigade-work or microwork.

Another question was: Have you ever required for a job through any social media? We received 235 answers. Only 43 respondents (18.3\%) did request someone for a job repeatedly. 119 respondents (50.6\%) never requested anybody for a job through social media.Detailed data represent the Figure 5 below.

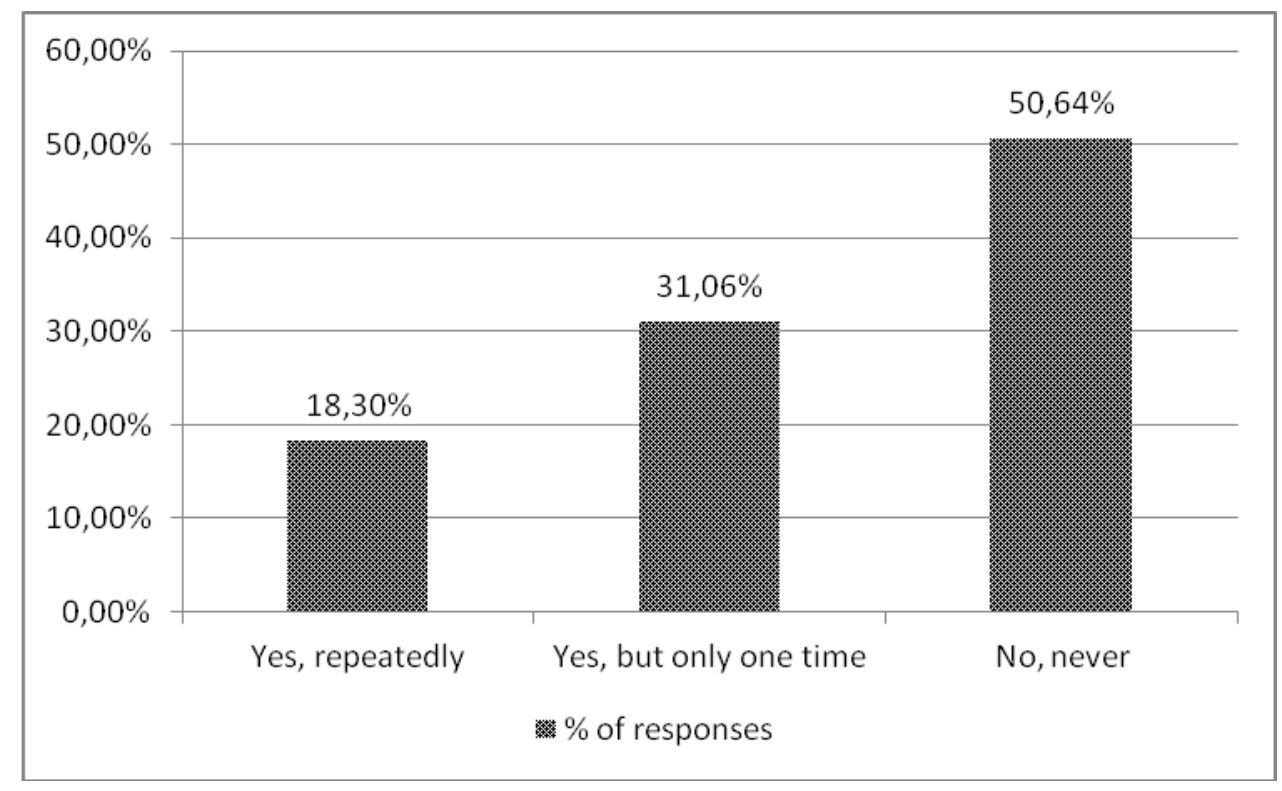

Figure 6. Have you ever required for a job through any social media? Source: Authors. 
We can claim that university students from Faculty of social-economic relation mostly react on job opportunities through the social media, rather than request someone to get a job. There is superiority of job offers on request of job in the group of students from the Faculty of social-economic relations.

The next question was "Did you get in the past a job through social media?" $46(19.4 \%)$ students answered yes, several times and 51 other ones $(21.5 \%)$ got a job through social media only once. The most of the respondents 140 (59.1\%) don't have any experience with getting a job through social media. Detailed data represent the Figure 6 below.

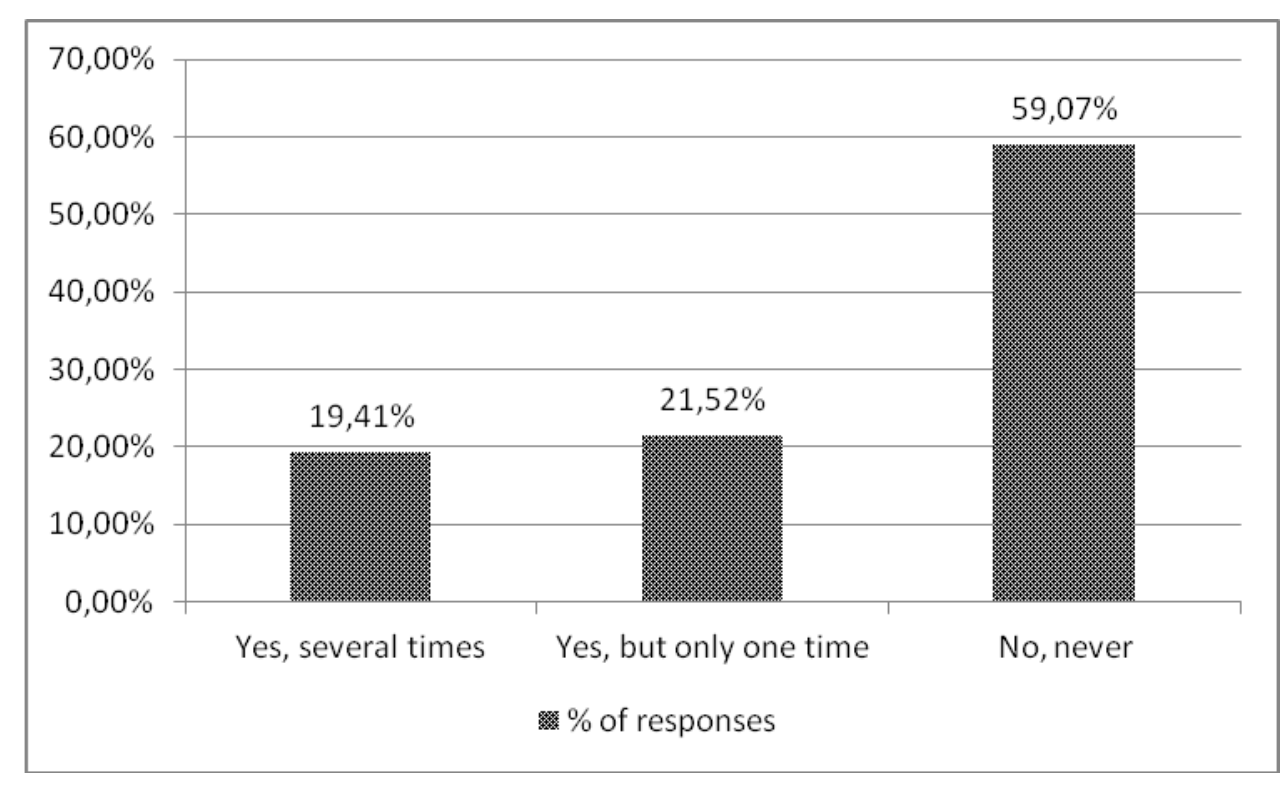

Figure 7. Did you get a job through any social media in the past?

Source: Authors.

Majority of students doesn't have any experience with job which was offered or obtained through any social network.

The question "Do you consider social media as a place where you can find a job or a place where a potential employer can find you?" $44.3 \%$ of respondents answered absolutely yes or rather yes. $40.5 \%$ of respondents answered rather no or absolutely no. $15.2 \%$ of students do not consider social media as a place to find a job. Exact answers we can find in the figure below. 


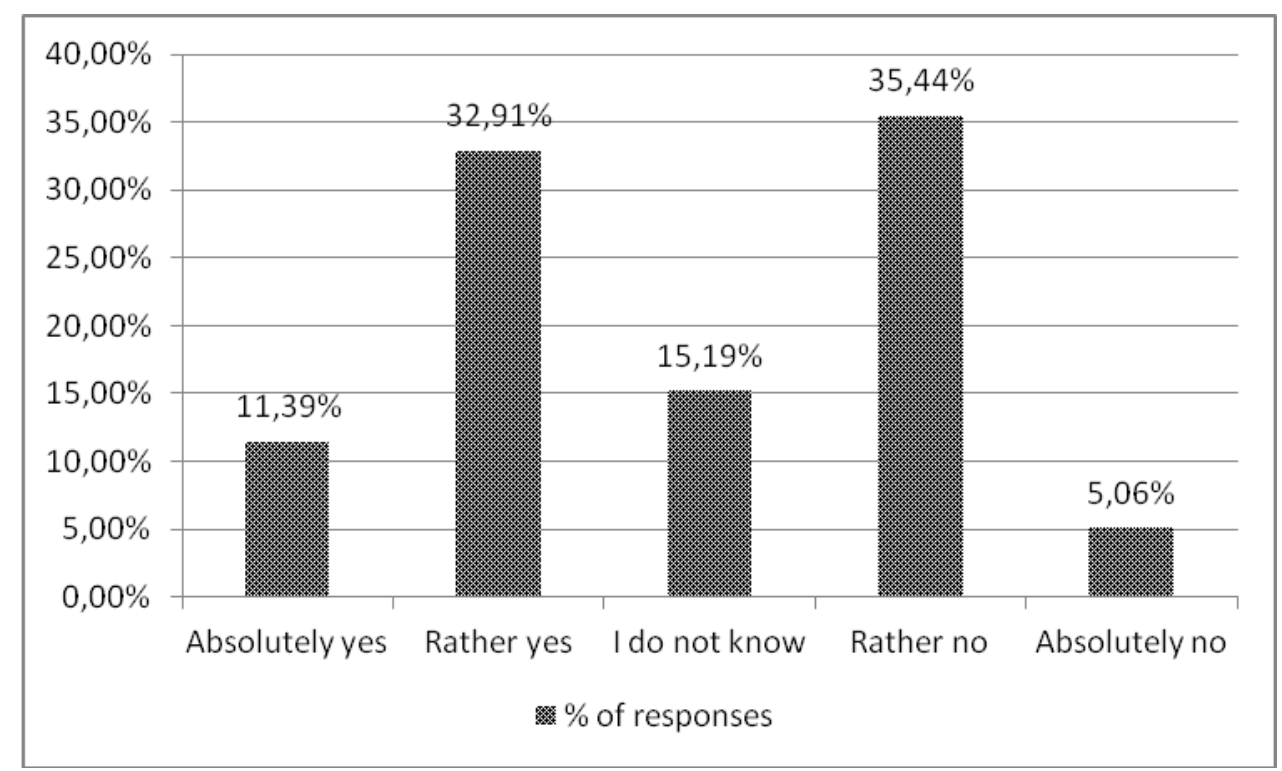

Figure 8. Do you consider social media as a place where you can find a job, eventually a place where potential employer can find you?

Source: Authors.

As we can see, there is not unity in attitudes. Only $11.4 \%$ of students consider social media as a place where they can find a job.

In the other question we investigate attitudes of students to importance of selfpresentation on social media from the perspective of job searching. $25.3 \%$ of respondents answered absolutely yes and $35.9 \%$ of respondents answered rather yes. Relatively big group of respondents $(17.7 \%)$ do not answered on this question. $18.1 \%$ of respondents answered rather no and only $3.0 \%$ of respondents answered absolutely no. All answers are presented in Figure 9.

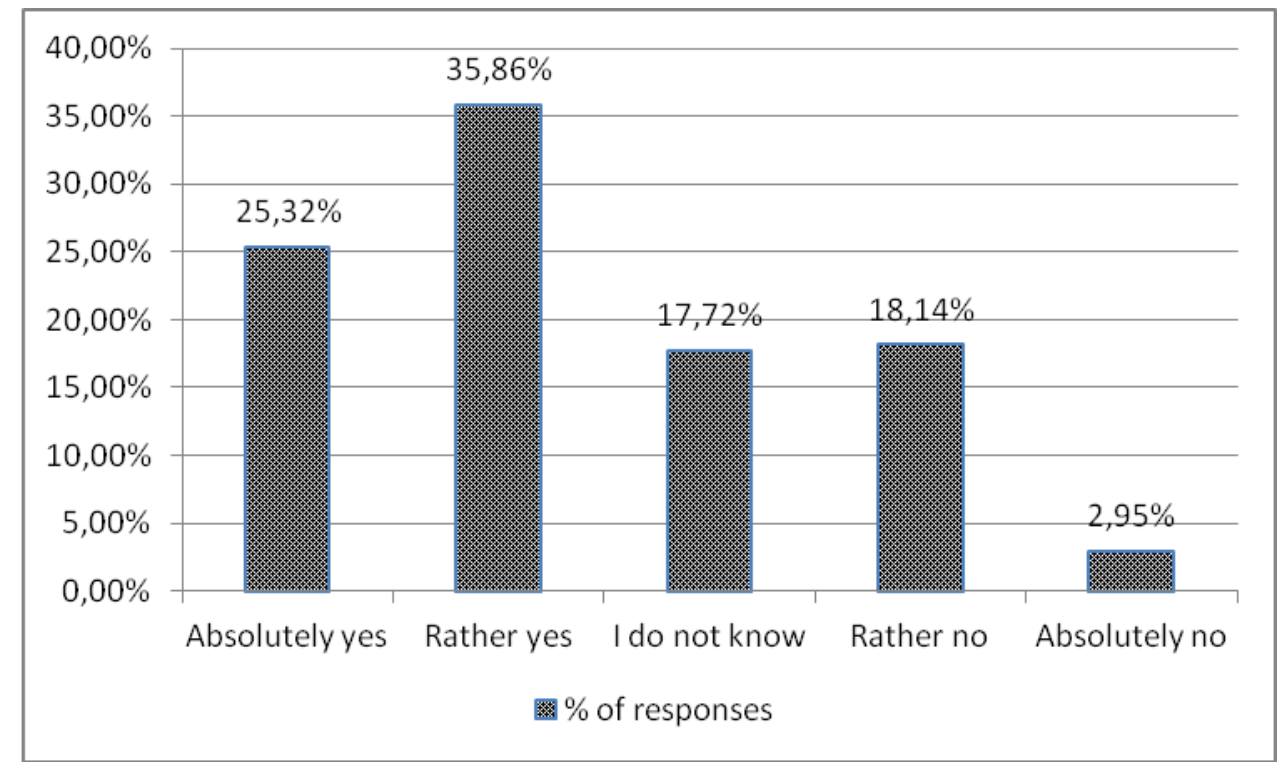

Figure 9. What do you think, is presentation of yourself on social media important from the view of job searching?

Source: Authors. 
Most of young people (61.2\%) from our survey consider self-presentation on social media as important from the view of job searching, but only $44.3 \%$ of respondents consider social media as a place on where you can find a job or place where potential employer can find them.

For statistical investigation we selected 6 questions from the questionnaire. It was assessed extra according to gender. The main purpose of the assessment of these questions was to verify hypotheses $\mathrm{H} 1_{0}, \mathrm{H} 2_{0}, \mathrm{H} 3_{0}$. For the statistical analyses we used specialized software STATISTICA 12.

- H10: We suppose that the gender difference of respondents does not have statistically significant effect on the Internet utilization for job search by Alexander Dubček University of Trenčín students.

- $\mathrm{H} 1_{1}$ : We suppose that the gender difference of respondents does have statistically significant effect on the Internet utilization for job search by Alexander Dubček University of Trenčín students.

- $\mathrm{H} 2_{0}$ : We suppose that the gender difference of respondents does not have statistically significant effect on perceiving of the importance of social networks from the point of view of job search neither nowadays nor in the future.

- $\mathrm{H} 2{ }_{1}$ : We suppose that the gender difference of respondents does have statistically significant effect on perceiving of the importance of social networks from the point of view of job search neither nowadays nor in the future.

- $\mathrm{H} 3_{0}$ : We suppose that the gender difference of respondents does not have statistically significant effect on perceiving of the importance of personal presentation on social networks from the point of view of job search.

- $\mathrm{H} 3_{1}$ : We suppose that the gender difference of respondents does have statistically significant effect on perceiving of the importance of personal presentation on social networks from the point of view of job search.

We suppose that the gender difference of respondents does not have statistically significant effect on perceiving of the importance of personal presentation on social networks from the point of view of job search neither nowadays nor in the future.

Following questions were assessed:

- Do you use possibility of internet (except social media) for looking a work occasions?

- Have you ever got a job offer through any social media?

- Have you ever required for a job through any social media?

- Did you get a job through any social media in the past?

- Do you consider social media as a place where you can find a job, eventually a place where potential employer can find you?

- What do you think, is presentation of yourself on social media important from the view of job searching?

First the null and alternative hypotheses about (in) dependence between observed variables were formulated and tested at significance level of $\alpha=0.05$. The hypotheses testing were performed by using Pearson's chi-squared test. 
Table 5. Chi-squared test - the Internet utilization in order to look for a job

\begin{tabular}{lcccc}
\hline \multicolumn{1}{c}{ Question } & Mean $\bar{x}$ & $\begin{array}{c}\text { Std. } \\
\text { Dev. } \mathrm{s}_{\mathrm{x}}\end{array}$ & $\begin{array}{c}\mathrm{p}- \\
\text { value }\end{array}$ & $\mathrm{H}_{0}$ \\
\hline $\begin{array}{l}\text { Do you use possibility of internet (except } \\
\text { social media) for looking a work occasions? }\end{array}$ & 1.031 & 1.032 & 0.072 & not rejected \\
\hline
\end{tabular}

Source: Authors.

The difference between male and female in the Internet utilization frequency for mentioned purposes we do not consider to be statistically significant considering the achieved significance level ( $\mathrm{p}$-value $=0.072$ ). We accept null hypothesis of Chi-squared test and we confirm working hypothesis $\mathrm{H} 1_{0}$.

Table 6. Chi-squared test - on perceiving of the importance of social networks from the point of view of job search neither nowadays nor in the future to look for a job

\begin{tabular}{lcccc}
\hline \multicolumn{1}{c}{ Questions } & Mean $\bar{x}$ & $\begin{array}{c}\text { Std. } \\
\text { Dev. } \mathrm{s}_{\mathrm{x}}\end{array}$ & $\begin{array}{c}\mathrm{p}- \\
\text { value }\end{array}$ & $\mathrm{H}_{0}$ \\
\hline Have you ever got a job offer through any social media? & 0.880 & 0.878 & 0.110 & $\begin{array}{c}\text { not } \\
\text { rejected }\end{array}$ \\
\hline Have you ever required for a job through any social media? & 0.773 & 0.766 & 0.420 & $\begin{array}{c}\text { not } \\
\text { rejected }\end{array}$ \\
\hline Did you get a job through any social media in the past? & 0.794 & 0.794 & 0.973 & $\begin{array}{c}\text { not } \\
\text { rejected }\end{array}$ \\
\hline $\begin{array}{l}\text { Do you consider social media as a place where you can } \\
\text { find a job, eventually a place where potential employer } \\
\text { can find you? }\end{array}$ & 1.156 & 1.156 & 0.570 & $\begin{array}{c}\text { not } \\
\text { rejected }\end{array}$ \\
\hline
\end{tabular}

Source: Authors.

We do not consider this difference between male and female to be statistically significant considering p-level, i.e. we accept null hypothesis of Chi-squared test and we confirm working hypothesis $\mathrm{H} 2_{0}$.

Table 7. Chi-squared test - of perceiving of the importance of personal presentation on social networks from the point of view of looking for a job

\begin{tabular}{lcccc}
\hline Question & Mean $\overline{\mathrm{x}}$ & Std. Dev. $\mathrm{s}_{\mathrm{x}}$ & $\mathrm{p}$-value & $\mathrm{H}_{0}$ \\
\hline $\begin{array}{l}\text { What do you think, is presentation of yourself on } \\
\text { social media important from the view of job searching? }\end{array}$ & 1.134 & 1.134 & 0.721 & $\begin{array}{c}\text { not } \\
\text { rejected }\end{array}$ \\
\hline
\end{tabular}

\section{Source: Authors.}

The difference between male and female in perceiving of the importance of personal presentation on social networks from the point of view of looking for a job for mentioned purposes we do not consider to be statistically significant considering the achieved significance level ( $\mathrm{p}$-value $=0.721)$. We accept null hypothesis of Chi-squared test and we confirm working hypothesis $\mathrm{H} 3_{0}$. 


\section{Similar researches}

There were not too many similar studies in Slovakia which focused on potential of social media in job searching.

In survey realized by consultancy company PriceWaterHouseCoopers (2012) in 2012 only $10 \%$ of students used Facebook for job searching. Yet $93 \%$ of them used Facebook regularly. Only $12 \%$ of them had LinkedIn account. Our survey shown that that numbers are going up.

According to the survey from 2014, realized by personal agency Grafton recruitment (2010 respondents - job candidates), 54\% of candidates used social media for job searching. According to this survey 9 of 10 personalists used LinkedIn and 30\% of them used Facebook during their work.

By Jobvite Social recruiting survey 2014 (1855 respondents - HR professionals and recruiters across industries in the USA) $94 \%$ of companies use for recruiting LinkedIn, $66 \%$ Facebook, 52\% Twitter, 21\% Google+ and 15\% Youtube (Jobvite, 2014).

The percentage of companies that use social networking sites to research job applicants has been steadily growing, from $39 \%$ in 2013, up to $43 \%$ in 2014, and $52 \%$ in 2015 according to CareerBuilder's annual social media recruitment survey (Careerbuilder, 2015).

\section{Conclusion}

With increasing requirement for flexibility and mobility and accelerating tempo in the process of obtaining and processing information the availability of information independently on time and place gains increasingly importance (Kajanová, Sedláček, 2014). The Internet and mobile technologies, social media and social networks became a part of everyday life of young people. The Internet became a fundamental tool for successful job search and not only personalists but also job candidates are aware of it. (Potkány et al., 2013).

We can claim that personal profile on any social media is very strong tool for the potential candidates to get a job. Of course it can also be an obstacle (in getting a job) because of inappropriate status, images or comments. For some recruiters it is a weak point of the candidate if they have absence from social media. Good profile and comfort behavior on the social media is very important.

According to our experience, previous works and this research we can summarize what are contemporary trends in job searching through social media:

- Importance of digital profiles in social media is increasing. For current job candidates actualized profile on any kind of social media is the key for success. Of course there is another ways to how to present yourself on virtual world. Such tools are personal website, personal blog or digital portfolio of works and projects.

- We can say that from the perspective of job searching on social media LinkedIn is a King. At the moment, a large proportion of job postings for professional roles and applications happen on LinkedIn. The role of facebook.com and twitter.com is also increasing.

- Almost all recruiters monitor potential candidates on social media sites or verify their abilities or skills through their connections, references and portfolio of works.

- Creativity and the ability to distinguish from another candidates has significant role. This refers also to employers who through communication on social media sites try to impress right candidates.

- Another trend in social media is mutual interactions between users, mutual evaluation and confirmation of skills. 
- There is a potential for creation new platforms and start-ups which will be intermediators between job searches and employers.

- Especially IT companies and some other technical oriented companies try to find the best candidates directly on universities or with cooperation of job angels or via specialized websites, platforms and hiring projects.

We assume that potential of social media in job searching will be very high in the future. Not only the importance of social media in job searching will rise, but for some occupations mainly professional social media sites (e.g. LindedIn.com nowadays) will become the only and exclusive way to get a job.

The main deductions from our survey we can resume as:

- Young people spend a lot of time on the internet and especially on social media. In our survey $30.1 \%$ of the respondents spend on the social media more than 4 hours. It's a quite long time spend in the virtual world.

- University student from our survey use social media mainly for other activities as job searching. This main activities are fun, relax, connection with friend and family.

- However they think social media is a place where they can find a job or where they can be contacted by recruiter/potential employer.

- In the sphere of job opportunities young people (university students) react more on outside impulse instead of they are initiative themselves.

- According to our survey almost $70 \%$ of respondents got a job offer through social media sometimes. More than a half of respondents made use of social media to get a job.

- More than $40 \%$ of respondents affirmed that they got a job through any social media in the past. Half of them got a job repeatedly.

- The fact that more than $2 / 5$ of respondents consider social media as a place where job opportunities can be found is also very important.

- More than $60 \%$ of respondents consider self-presentation on social media as important from the view of job searching.

As shown in our survey, young people spend a lot of time on social media sites. Besides fun and contacting friends and families, using social media in order to find a job becomes more and more important. The area of using social media in job searching is very dynamic. There is a wide scope for other researches in the future. In this field new methods, mobile applications and start-ups which constantly change the labour market and job searching are developed.

Kajanová (50\%) - Sedláček (40\%) - Soósová (10\%).

\section{References}

Bencsik, A., Horváth-Csikós, G., Juhász, T. (2016), Y and Z Generations at Workplaces, Journal of Competitiveness, Vol. 8, Issue 3, pp. 90-106.

Bissola, R., Imperatori, B. (2014), Recruiting Gen Yers Through Social Media: Insights from the Italian Labor Market, In: Tanya Bondarouk, Miguel R. Olivas-Luján (ed.), Social Media in Human Resources Management, Advanced Series in Management, Vol. 12, Emerald Group Publishing Limited, pp. 59-81.

Boswell, W. R., Zimmerman, R. D., Swider, B. W. (2012), Employee job search: Toward an understanding of search context and search objectives, Journal of Management, Vol. 38, Issue 1, pp. 129-163. 
Boyd, D. M., Ellison, N. B. (2007), Social Network Sites: Definition, History, and Scholarship, Journal of Computer - Mediated Communication, Vol. 13, issue 1, pp. 210-230.

Careerbuilder (2015), Post, tweet, pin, follow: How social media can help - and hurt - the job hunt, http://advice.careerbuilder.com/posts/post-tweet-pin-follow-how-social-mediacan-help-and-hurt-the-job-hunt (referred on 22/02/2016).

Colas-Bravo, P., Gonzalez-Ramirez, T., de Pablos-Pons, J (2013), Young People and Social Networks: Motivations and Preferred Uses, Comunicar. Vol. XX, Issue 40, pp. 15-23.

Jobvite (2014), Jobvite Social recruiting Survey 2014, https://www.jobvite.com/wpcontent/uploads/2014/10/Jobvite_SocialRecruiting_Survey2014.pdf (referred on $12 / 02 / 2016)$.

Jobvite (2016), 2016 Job Seeker Nation report, http://web.jobvite.com/Q116_SocialMedia_2016JobSeekerNation_LP.html?utm_source =blog\&utm_medium=social\&utm_campaign=2016jobseekernation (referred on 30/03/2016).

Kajanová, H., Sedláček, M. (2014), Readiness of students to use M-learning in education case study Slovakia, In: SGEM conference on psychology \& psychiatry sociology \& healthcare education: Conference proceedings volume III Education \& educational research. Sofia: STEF92 Technology, pp. 737-744.

Kaplan, A. M., Haenlein, M. (2010), Users of the world, unite! The challenges and opportunities of Social Media, Business Horizons, Vol. 53, Issue 1, pp. 59-68.

Kietzmann, J. H., Hermkend, K., McCarthy, I. P., Silvestre, B. S. (2011), Social media? Get serious! Understanding the functional building blocks of social media, Business Horizons, Vol. 54, Issue 3, pp. 241-251.

Leonardi, P. M., Huysman, M., Steinfield, Ch. (2013), Enterprise Social Media: Definition, History, and Prospects for the Study of Social Technologies in Organizations, Journal of Computer-Mediated Communication, Vol. 19, Issue 1, pp. 1-19.

Miller-Merrell, J. (2016), 5 Powerful Recruiting Trends in 2016, http://www.jobvite.com/blog/5-powerful-recruiting-trends-in-2016/ (referred on 30/03/2016).

Parker, S. (2014), Seasonal Hiring Fix: Social Recruiting, https://www.jobcast.net/seasonalhiring-fix-social-recruiting/ (referred on 30/03/2016).

Potkány, M., Sedláček, M., Hajduková, A., Hitka, M. (2013), Utilization and the Effect of Social Networks on Job Search of Slovak University Students, WSEAS Transactions on advances in engineering education, Vol. 10, Issue 3, pp.91-100.

PriceWaterHouseCoopers (2012), Študenský barometer 2012, http://www.pwc.com/sk/sk/publikacie/assets/2012/pwc-studentsky-barometer-2012.pdf (referred on 25/02/2016).

Swallov, E. (2011), How Recruiters Use Social Networks to Screen Candidates, http://mashable.com/2011/10/23/how-recruiters-use-social-networks-to-screencandidates-infographic/\#xoLN2ZBE0Pq3 (referred on 30/03/2016).

ŠÚ SR (2016), Nezamestnanost' v 3. štvrt'roku 2016.

Top-Consultant (2016), Top-Consultant.com's Management Consultancy Recruitment Channel Report 2016, http://www.top-consultant.com/topconsultant_2016_recruitment_channel_report.pdf (referred on 15/02/2017).

UPSVAR (2017), Nezamestnanost', 2016, http://www.upsvar.sk/buxus/generate_page.php?page_id=582328 (referred on 15/02/2017).

Velšic, M. (2015), Digitálna gramotnost’ na Slovensku 2015, Inštitút pre verejné otázky, Bratislava. 
Vlačuha, R., Kotlár, J., Želonková, V. (2013), Prieskum o využivaní informačných a komunikačných technológii v domácnostiach za 1. štvrtrok 2013, ŠÚ SR, Bratislava, p. 37.

Zanella, S., Pais, I. (2014), \#Social recruiting (A global Study) - Job Search, Digital Reputation, and HR Practices in the social media age, The Adecco Global Study 2014, http://www.adecco.com/en-US/Industry-Insights/Documents/social-recruiting/adeccoglobal-social-recruiting-survey-global-report.pdf (referred on 22/03/2016).

Zheng, R., Cheok, A. (2011), Singaporean Adolescents' Perceptions of On-line Social Communication: An Exploratory Factor Analysis, Journal Educational Computing Research, Vol. 45, Issue 2, pp. 203-221. 